SALAM; Jurnal Sosial \& Budaya Syar-i

FSH UIN Syarif Hidayatullah Jakarta

Vol. 7 No. 11 (2020), pp. 1053-1062, DOI: 10.15408/sjsbs.v7i11.17793

\title{
Saatnya Azas Demokrasi Dikembalikan Bersumber Norma Moral ${ }^{*}$
}

\author{
M. Makhfudz ${ }^{1}$ \\ Dosen Fakultas Hukum Universitas Tama Jagakarsa, Jakarta \\ 10.15408/sjsbs.v7i11.17793
}

\begin{abstract}
s:
Natural laws are vague and metaphysical, but that does not mean they are permanently stuck in the clouds. And when natural law is thought to exist only in the cloud, there would be no gain that can be gained from the positive law that applies in a region. However, as fundamental principles of natural law come to the fore in the way that their rules are converted into actual situations, the advantages of new natural laws are of considerable value to mankind. The composition of this paper employs a qualitative analysis process with a literary approach from a variety of literatures. The findings of the study suggest that it is important to restore democracy on the basis of moral norms.

Keywords: Values, Democracy, Rules of Justice
\end{abstract}

\begin{abstract}
Abstrak :
Hukum alam bersifat abstrak dan teoritis, namun tidak berarti bahwa hukum alam selamanya tergantung di awang-awang. Sebab ketika hukum alam dianggap hanya ada di awangawang, maka akan tidak banyak manfaatnya yang dapat dipetik oleh hukum positif yang berlaku di suatu Negara. Akan tetapi, ketika kaidah hukum alam yang abstrak turun ke membumi dalam arti kaidah-kaidahnya diejawantahkan ke dalam kasus-kasus konkret, maka manfaatnya hukum alam baru sangat terasa manfaatnya bagi umat manusia. Penulisan artikel ini menggunakan metode penelitian kualitatif dengan pendekatan kepustakaan dari beberapa literatur. Hasil penelitian menyatakan perlu mengembalikan demokrasi dengan bersumber kepada norma moral.
\end{abstract}

Kata Kunci: Azas, Demokrasi, Norma Moral

* Received: July 13, 2020, Revision: July 18, 2020, Published: November 1, 2020.

${ }^{1}$ M. Makhfudz adalah dosen tetap Fakultas Hukum, Universitas Tama Jayakarsa Jakarta. E-mail: mmakhfud12@gmail.com 


\section{Makhfudz}

\section{A. PENDAHULUAN}

Pengertian Demokrasi yang berasal dari kata Yunani yang terdiri dari demos dan kratos. Demos sering dimaknai Rakyat dan Kratos sebagai Kekuasaan. Jadi demokrasi berarti "Kekuasaan oleh Rakyat". Namun pengertian itu telah lama mengalami pendangkalan dan pengaburan makna, khususnya di Indonesia. Sebab demokrasi dalam pengertian tersebut cenderung dimaknai sebagai kekuasaan memutus perkara dan atau pilihan atas dasar ukuran (suara) mayoritas. Dalam pemaknaan tersebut, demokrasi cenderung direduksi menjadi sekedar soal kuantitas, mekanisme pengambilan keputusan berdasarkan voting seolah demokrasi hanya sekedar hiasan belaka yaitu unsur "Rakyat" yang memonopoli lembaga-lembaga kekuasaan atau adanya rakyat yang memiliki kekuasaan monopolistic diantara pemegang kekuasaan lain dalam sebuah Negara.

Makna sejati dari demokrasi adalah "kekuatan dan kemampuan kolektif" untuk bertindak mewujudnyatakan kebaikan umum. Praktik berdemokrasi di zaman dulu di Yunani kuno tidak melulu berpusat pada voting. Tapi voting hanya sebuah sarana mekanisme pengambilan keputusan tidak dimungkiri, namun prinsif utamanya adalah voting untuk kemaslahatan demos. Hal ini berarti demos bukan semata jumlah, bukan pula semata kumpulan individu. Tapi merupakan kesatuan jiwa raga warga Negara yang latar belakang sosialnya berbeda, unik dan dia masing-masing memiliki hak kebebasan untuk memilih sesuai dengan yang dikehendaki. Maka, makna menjalankan pemerintahan ada sebuah perintah yang dimaknai, menurut pendapat HLA Hart menyatakan bahwa "To exercise authority overmen, not power to inflict harm, and thought it may be combined with threats of harm the command esprimarily an appeal non fear but to respect for authority". ${ }^{2}$ Artinya makna perintah adalah suatu tindakan melaksanakan kekuasaan terhadap seseorang bukan berarti kekuasaan untuk menyakiti atau menimbulkan kerugian, meskipun perintah yang bersangkutan mungkin saja terjadi bersama-sama dengan ancaman untuk jadinya bahaya tersebut. Seperti kala ini sedang terjadi, dengan pembahasan RUU HIP, usulan DPR yang aslinya konon berbeda judulnya yaitu RUU Pembinaan Ideologi Pancasila bukan RUU Haluan Ideologi Pancasila. Jadi semula hanya sebuah pedoman untuk pelaksanaan BPIP (Badan Pembinaan Ideologi Pancasila / semacam TUPOKSI BPIP), tapi sesampainya ke meja. Peristiwa ini penulis sebut, pelaksanaan demokrasi yang sudah melanggar moral. Karena ada motif menjebak atau bohongi rakyat dari kelengahan, ditengah keresahan rakyat hadapi pandemi wabah covid yang tiada akhir.

Dalam konteks itu, demokrasi berarti sejatinya diperuntukkan untuk beri kesempatan yang sama bagi warga negara terhadap barang public, kratos berarti kapasitas kekuasaan public, yang dijalankan pemerintah, untuk mewujudkan kebaikan umum melalui melaksanaan kebijakan dan tindakan baik di ramah baik, tidak memenuhi syarat moral. Singkat kata, demokrasi adalah narasi kekuasaan yang melindungi dan memenuhi hak asasi manusia. Sebab pada hak asasi manusialah esensi dan martabat demos yang sesungguhnya.

\footnotetext{
${ }^{2}$ Munir Fuady. Teori-teori Besar Dalam Hukum, Penerbit Kencana, Jakarta, 2013, hal. 98.
} 
Dengan pemaknaan, kratos minus demos yang disebut tidak berarti sematamata kekuasaan (pemerintahan) minus rakyat secara kuantitas. Kratos minus demos yang dimaksud adalah kekuasaan pemerintahan demokrasi yang bisa saja, melibatkan rakyat, lewat politik, procedural pemilu massal, namun tidak fungsional menghormati, melindungi dan memenuhi hak asasi manusia.

Kekuasaan yang tidak memiliki kapasitas untuk mewujudkan kebaikan umum, keadilan, kedamaian dan kesejahteraan. Kekuasaan pemerintahan tanpa daulat rakyat! Dan itu yang kini terjadi. Rakyat tak terdengar suaranya tapi menonjol identas partainya/kelompoknya. Seperti data yang layak mendapatkan Bansos, tidak berdasar data base yang ada pada masyarakat karena dibuat entah kapan? Demikian pula BLT, sehingga bansos yang selayaknya menciptakan kebaikan berupa kesejahteraan saat rakyat dilanda krisis akibat pandemic, malahan melahirkan kekisruhan, aksi protes pada pejabat paling bawah ada yang sampai Bapak Lurah yang baru diangkat lebih baik mundur, melepaskan jabatannya.

Penulis banyak catatan kebobrokan saat ini dari para pelaksanaan pemerintahan dalam melaksanakan kekuasaan yang tidak memperlihatkan perintah hukum, seperti menghapus data orang penting di negeri ini. Contoh data pelarian koruptor BLBI. Bank Bali, Joko Candra yang oleh pejabat lama masukan data DPO pelarian di luar negeri, kini oleh penguasa baru dihapus dengan mudahnya, sehingga ketika nongol di Pengadilan Negeri di Negeri sendiri. Ada pejabat yang masih pegang komitmen kebenaran menanyakan status DPO yang bersangkutan. Dengan entengnya dijawab oleh pejabat dari rezim ini, data DPO tidak ada lagi padahal yang bersangkutan dikenal di seantero jagat raya, status DPO. Kalau penulis soroti hal itu bisa dimakhlumi, kejadiannya sudah lama, tapi kasus paling anyar Harun Masiku yang menimpa Komisioner KPU perihal suap PAW, kader partai penguasa. Kasus terjadi masih seumur jagung, juga datanya dengan mudahnya dihapus dari data base ke Imigrasian. Padahal penulis mencatat kejadian tersebut masuk yang melanggar moral, karena memiliki motif kebohongan belaka. Karena konon menyangkut figure dari kelompok partai penguasa. Yang kala itu justru pejabat imigrasi yang memberi keterangan bahwa H.M. telah kembali ke tanah air, kemudian demi keamanannya pejabat imigrasi yang memberi keterangan segera dipecat dan H.M. dari data bepergian ke luar negeri juga ikut dihapus.

\section{B. METODE PENELITIAN}

Metode penelitian yang digunakan adalah metode kualitatif berbasis kepustakaan (library research). Pendekatan yang digunakan adalah deskriptif kualitatif yang bertujuan untuk memberi gambaran atau mendeskripsikan kenyataan yang ada atau apa yang terjadi atau kenyataan sebenarnya pada obyek yang diteliti. Hal yang menjadi fokus peneliti adalah realita demokrasi yang belum membumi pada kehidupan masyarakat luas, sehingga dirasa penulis perlu mencari azas yang tepat berupa norma moral sebagai azas demokrasi. 


\section{Makhfudz}

Selain, penelitian ini dilakukan dengan pengamatan dari jauh tentang sikap para pelaku pemegang kekuasaannya dalam menjalankan kewenangannya, yang cenderung masuk kateogir melanggar nilai-nilai norma moral. Fenomena yang memperhatinkan para pengambil kebijakan kini makin abai terhadap pentingnya norma moral, sehingga dengan bebasnya melakukan apa saja dianggap benar. Tak peduli masuk melanggar norma moral atau tdaik.

\section{ANALISIS DAN PEMBAHASAN}

\section{Hakikat Demokrasi}

Fenomena praktik pemerintahan yang demokrasi banyak macamnya, dengan macam cara licik dimana istilah kratos minus demos bisa disebut tidak berarti sematamata kekuasaan (pemerintahan) minus rakyat secara kuantitas. Kratos minus demos yang dimaksud adalah kekuasaan pemerintahan demokrasi yang bisa saja melibatkan rakyat, lewat politik, procedural pemilu/pilkada misalnya, namun tidak fungsional menghormati, melindungi dan memenuhi hak asasi manusia.

Kekuasaan yang tidak memiliki kapasitas untuk mewujudnyatakan kebaikan umum, keadilan, kedamaian dan kesejahteraan. Semua fenomena tersebut alih-alih hanya menghasilkan pemerintahan dan kekuasaan yang berbasis pada daulat rakyat, demokrasi justru memproduksi rezim kekuasaan pemerintahan yang doyan menciderai dan memerkosa hak-hak rakyat.

Demokrasi kini sedang mengalami permasalahan rumit, karena sejumlah problematika bangsa yang pelik dan multi komplek, baik dari dalam maupun dari luar dirinya. Mulai dari faktor dominasi kepentingan politik dari kelompok penguasa untuk mengumpulkan figur-figur bangsa yang satu ideologi walau pendatang baru, seperti munculnya figur yang diangkat sebagai Ketua BPIP (Badan Pembinaan Ideologi Pancasila) yang awal sering membuat pernyataan di media publik yang kontroversial, seperti menyatakan musuh Pancasila adalah agama yang paham khilafah yang cenderung adu domba. Semua itu ikut serta memperkeruh proses menciptakan pemerintahan yang kratos minus demos, menambah matinya proses pemberdayaan rakyat dalam pemerintahan demokrasi. Kini muncul lagi permasalahan pelik mulai terlibat ketakberdayaan pemerintah memenuhi ekspektasi rakyat, menguatnya kecenderung urusan publik dan sumber daya dieksplotasi kekuatan neoliberalisme dan globalisasi (fundamentalisme pasar dan fundamentalisme agama). Representasi yang buruk adalah mata rantai kedaulatan rakyat, maraknya kekerasan vertikal dan horizontal, Sosial dan ekonomi lebih lamanya pandemic wadah virus Covid 19, rapuhnya konsolidasi masyarakat sipil, sampai dengan ketiadaan alternatif kepemimpinan dan kelembagan politik. Pertanyaan mandasar, dalam kondisi demikian, haruslah demokrasi disingkirkan? bisa penulis tunjukkan dalam hadapi pandemik, pemerintah menetapkan UU Darurat dengan mencantumkan klausul pertimbangan, perundangan ini tidak bisa diganggu gugat dalam sebuah perbuatan pidana, klausul ini pernah terjadi disaat pemerinth orde lama yang pelaksanaannya cenderung otoritere, 
kini terjadi ulang yang peneliti simpulkan ini masuk kelompok kebijakan penguasa yang langgar norma moral.

\section{Hubungan Hukum dan Moral}

Dalam benah penulis hubungan "hukum dan moral" ibarat dua sisi mata uang, dimana sisi yang satu dengan lainnya saling berkaitan karena yang satu dapat menjustifikasi yang lainnya. Sebab "moral" dapat menjadi basis (dasar) bagi hukum untuk menetapkan dan menjalankan kaidah-kaidahnya, meskipun ada juga pihak lain yang mengklaim kaidah hukum ada yang tidak berkaitan dengan moral dalam arti kecil, tetapi dalam prakteknya untuk memisahkan sangat sulit.

Di sini penulis akan jelaskan pengertian "moral" dalam bukunya yang berjudul “Teori-teori Besar Dalam Hukum” yang ditulis oleh Munir Fuady. Disebutkan bahwa "Moral" adalah "Segala penilaian, ukuran, karakter, perilaku, kesadaran, yang berhubungan dengan apa-apa yang baik dan apa-apa yang buruk, atau mana yang benar dan mana yang salah, berdasarkan kepada prinsip-prinsip umum diberlakukan berdasarkan atas kesadaran manusia, yang berasal dari perasaan. ${ }^{3}$

Namun yang dijumpai sesuatu yang hidup dalam masyarakat banyak adalah bahwa "Moralitas Sosial" memiliki karakteristik berupa "nilai" yang suci yang merupakan kebijakan yang abadi yang bersumber pada akal pikiran manusia (human reason). Dari sudut ini, maka kaidah moral menjadi mirip dengan kaidah hukum. Penulis menggambarkan hubungan "moral" dengan "hukum" dalam implementasinya, ketika unsur moral dioperasionalkan, maka moral tidak lain dari segala sesuatu yang baik dan sesuatu yang menjadi baik manakala dia dapat berfungsi dengan baik, artinya bila calon pemimpin yang dipilihnya berguna bagi masyarakat atau dia dapat menjalankan fungsinya secara efisien yang dilandasi tanggung jawab moral dalam hatinya untuk menjadikan rakyat yang memilihnya bisa terangkat nasibnya dan tidak menggunakan jabatannya serta anggarannya untuk kepuasan dirinya maupun keluarganya. Artinya pemimpin yang disyarakatkan oleh aturan atau peraturan perundang-undangan tersebut menjadikan pemimpin tersebut tidak korupsi. Sebab korupsi menurut pendapat Simon bahwa korupsi adalah dari kata "strafbaarfeit" yang artinya jahat, jahil, curang, keji, sehingga sangat tidak sesuai moral sebagaimana pengertian di atas.

\section{Demokrasi dan Politik}

Demokrasi Indonesia secara lebih detail, memang digambarkan memang mengalami kemajuan saat baru lahirnya era reformasi disbanding sebelumnya. Yang penulis gambarkan yang mengalami kemajuan yaitu dari aspek kebebasan sipil politik, namun disaat bersamaan demokrasinya juga terjebak dalam perangkap demokrasi oligarki disatu sisi dan sisi lain kecenderungan tertib politik kurang kendali. Sebuah perkembangan yang membuat konsolidasi demokrasi rentan masuk ke dalam wilayah

${ }^{3}$ Munir Fuady. Teori-teori Besar Dalam Hukum, Penerbit Kencana, Jakarta, 2013, hal. 70. 


\section{Makhfudz}

"abu-abu" yang serba tak pasti dan cenderung terdistorsi, sering negeri ini diisi dengan deskripsi negara yang tidak akuntabilitas justru disaat prosedur demokrasi berlangsung dengan semangat. Bukannya semakin menghormati, melindungi dan memenuhi hakhak rakyat, negara dan pemerintah produk demokrasi justru terus abai dari tanggung jawab pemerintah dan terus membiarkan pelanggaran moral hak korban. Melalui praktik dan dinamika politik, baik level penguasa maupun di level rakyat. Ada yang alami sakit "obesitas politik" yang dialami partai politik, sehingga membuatnya gemuk dan power full, namun justru alami mal fungsi dan menurut penulis perlu didekonstruksi kembali. Hal terpenting bagaimana aspek politik menyangkut hajat hidup orang banyak, yaitu politik pangan yang dicengkeram kekuatan asing. Nilai-nilai pengharapan rakyat akan terjadi perubahan, apakah itu nilai akan demokratisasi, perlindungan hak asasi atau peningkatan tarap hidup yang lebih layak, pemberantasan korupsi, kolusi dan nepotisme, pemerintahan yang baik dan bersih. Tetapi justru kini KPK makin terpenjara oleh kekuasaan rezim yang terus menjepit kebebasan KPK dengan dibentuknya Dewan Pengawas. Yang kini KPK makin sempit ruang gerakknya untuk bongkar korupsi hadapi penguasa politik, seperti kala KPK hadapi kasus suap dalam kasus PAW anggota DPR dari kalangan partai penguasa dilakukan oleh Harun Masiku kini berstatus buron apa bukan?

\section{Puncak Pelanggaran Moral}

Penulis sebelum menunjukkan sebuah fenomena yang masuk dalam pelanggaran moral, terlebih dahulu akan menunjukkan sebuah teori. Teori tersebut berasal dari seorang sosiolog-positivistik yaitu bernama Emile Dur Kheim, yang kemudian disebut Teori Durkheim. Teori Durkheim suka menempatkan hukum sebagai moral social. Sebuah pertanyaan muncul, mengapa Durkheim suka memandang hukum sebagai "Unit moral social”. Emile Durkheim bukan seorang filsafat seperti Aristoteles, tapi ia seorang "sosiolog-positivis", yang selalu bergumul dengan faktafakta empiris berjejer dengan Marx dan Maine. Durkheim selalu berberinjak pada faktafakta empiris, yaitu dengan membangun teori dibawah tema "pembagian kerja". Pembagian kerja itu adalah sebuah fakta empiris, di dalam fakta pembagian kerja itu terdapat sebuah struktur social terancang-bangun.

Selanjutnya Durkheim berpendapat bahwa dalam pembagian kerja menentukan solidaritas social. Solidaritas itu sendiri merupakan unit yang abstrak. Ia merupakan "Roch" yang mengikat orang-orang pada kerangka keyakinan "bersama dalam membangun hidup yang terintegrasi. ${ }^{4}$ Itulah yang menurut Durkheim menyebut dimensi moral dari hukum itu sendiri. Tetapi bila berhenti sampai di sini, berarti mandeglah kerja sosiologi, tapi kerangka keyakinan, tetaplah sebuah unit yang abstrak. Kerangka keyakinan tidak merubah solidaritas social dan menjadi suatu yang empirik. Durkheim lalu mencari unit empiris dalam mozaik solidaritas social yang abstrak.

${ }^{4}$ William E. Evan, Social Structures and Law Dalam Buku Teori Hukum, Strategi Tertib Manusia Lintas Ruang dan Generasi, Penerbit Genta, Yogya, 2010, hal. 115. 
Akhirnya Durkheim menemukan hukum sebagai unit yang empiris dari solidaritas sosial.

Dari situ bisa menyimpulkan bahwa Durkheim menemukan hukum sebagai moral sosial yang mencerminkan bahwa hukum merupakan ekspresi solidaritas sosial yang berkembang dalam masyarakat. Durkheim menyebut bahwa tak ada masyarakat dimanapun yang dapat tegak dan eksis secara konstan dan terus-menerus tanpa adanya solidaritas. Sebagai tiang utama integrasi, solidaritas social bergerak dan berubah seirama dengan perkembangan sosial dalam masyarakat. Perkembangan dan perubahan dari tahap tradisional sampai tahap modern, selalu diikuti oleh pergeseran solidaritas dari yang mekanis sampai ke organis. Perkembangan itu sejalan dan seiring dengan kian terdiferensiasinya pembagian kerja didalam masyarakat itu. Dalam konsep Durkheim diprensiasi pembagian kerja yang merupakan tema sentral yang menjelaskan terjadinya berbagai macam perubahan dalam ihwal struktur dan restrukturasi masyarakat, tipe solidaritasnya dan pula fungsi hukumnya. ${ }^{5}$ Teori Marx dan Maine juga ikut mempengaruhi Durkheim, seperti tercermin dalam bukunya "Delavision du Travaill." Durkheim berpendapat system pembagian kerja dalam suatu masyarakat menentukan tipe solidaritas social yang terbangun dalam masyarakat tersebut.

Dalam masyarakat yang belum mengenal pembagian kerja yang beragam, maka terbangun solidaritas yang mekanis. Sedangkan dalam masyarakat yang telah mengenal diferensiasi kerja (fungsi, tugas dan keahlian), cenderung melahirkan solidaritas yang organis. Dua tipe solidaritas, menurut Durkheim menentukan wajah hukum.

Dalam solidaritas yang mekanis, bersemi hukum yang berkarakter menindak, sisi lain solidaritas membuahkan hukum yang berwatak memulihkan. ${ }^{6}$ Kedua watak hukum tersebut (hukum yang menindak dan hukum yang memulihkan), keduanya memiliki tujuan yang sama, yaitu "mempertahankan integrasi sosial."

Penulis simpulkan, kedua watak hukum itu berbeda jalan, tapi satu tujuan. "Hukum yang menindak", "jalan" (cara dan strategi) yang ditempuh masyarakat tradisionil, sedangkan masyarakat modern mengambil haluan yang berbeda yaktu lebih memanfaatkan "Hukum yang memulihkan". Tetapi penulis menyimpulkan pengetrapan hukum yang menindak di era millenea justru lebih sering dijumpai, sedangkan hukum yang memulihkan sebetulnya dikenakan pada obyek hukum dalam pengenaan sanksi bagi pelaku hukumnya yang belum memenuhi usia dewasa (alias untuk peradilan anak-anak).

Dari uraian di atas yang panjang lebar menjelaskan makna dari hukum sebagai "moral sosial" atau hukum yang didalamnya bersarang nilai moral sosial lingkungannya yang wajib dijaga.

Kini penulis menyimpulkan temuannya dalam penelitian ingin menyimpulkan dalam praktek pelaksanaan kebijakan Negara khususnya dalam penetapan perundangundangan yang masuk dalam tindak pelanggaran moral, kala kekuasaan dari partai yang sama kini berkuasa, namun berbeda pemimpinnya, yaitu pada saat penetapan

\footnotetext{
${ }^{5}$ Ibid., hal. 116.

${ }^{6}$ Ibid., hal. 116
} 


\section{Makhfudz}

Undang-Undang Nomor 13 tahun 2004 tentang kontrak kerja singkat. Karena setelah ditetapkannya Undang-Undang Nomor 13 tahun 2004 melahirkan suatu kekecewaan dikalangan pekerja, yang terus muncul di kala peringatan buruh internasional yang disebut May Day. Selalu jadi Tema Misi UU No. 13 Tahun 2004, sebagai protes atas dihapuskannya hak pekerja untuk mendapatkan pesangon. Apalagi kini di era kekuasaan partai yang sama maupun beda pemimpinnya lebih banyak aturan yang masuk kategori melanggar moral menurut Emile Durkheim seperti kala menetapkan UU KPK yang baru dengan pembentuk DEWAS (Dewan Pengawas), yaitu Undangundang Nomor 19 Tahun 2019 dengan segala teknik licik sudah diperlakukan secara paksa dengan memakai alat hukum yang berwatak menindak, yang membuat KPK kini tak bias bertindak menindak menunjukkan keperkasaannya, seperti kini KPK tak bisa grebek ke Kantor Partai, sekaligus juga tak bisa membongkar kasus suap yang menimpa Komisioner KPU dalam kasus PAW anggota DPR yang kini pekaku suapnya berstatus DPO Harun Masiku KPK kini bisa bergerak cepat, tangkap koruptor.

Undang-Undang Nomor 19 Tahun 2019 tentang perubahan kedua KPK, masuk kebijakan yang menurut teori Durkheim yang melanggar moral karena menimbulkan kekecewaan yang berakibat memudarkan nilai solidaritas sosial. Akan melahirkan kesan, pemerintahan melindungi koruptor, terbukti pelaku suap Harun Masiku yang tidak ditangkap, bahkan kini kebijakan partai penguasa melalui kadernya sedang berusaha sebarkan issue melalui media bayaran agar memberitakan Haru Masiku telah mati, ini bakalan menjadi catatan dosa yang tidak bisa dihapus dihati sebagian rakyat terhadap penguasa.

Disamping juga penulis dalam penelitiannya juga menemukan sebuah catatan rencana kebijakan Negara, lain yang bakal muncul yang kini sudah mulai dirintis dengan segala jalan licik yang sudah ditempuh, di tengah-tengah polemik yang masih ada pada sebagian kelompok masyarakat yaitu ada bagian kelompok bunglon karena wadahnya masuk koalisi penguasa yaitu GP Ansor menyatakan menolak isi omnibuslaw, utamanya yang tulen adalah kelompok ormas wadah cendikiawan muslim yaitu Muhammadiyah masih menolak dan kelompok ormas pekerja ancam akan demo besar-besaran. Tetapi penguasa rupanya sudah teguh akan memaksakan DPR supaya terus tetapkan aturan Omnibuslaw dengan segala materi yang telah mencabut hak-hak pekerja dan hak konsumen.

Penulis menyebut satu lagi kebijakan Negara yang masuk dalam pelanggaran moral menurut teori Durkheim yaitu ketika rancangan undang-undang usulan DPR yaitu RUU HIP (Rancangan Undang-Undang Haluan Ideologi Negara).

Penulis simpulkan ide HIP ini adalah sebuah sesuatu yang tertanam lama yaitu kala Pidato Presiden Pertama jelang-jelang keruntuhannya sekitar tahun 1960 yang disebutkan secara jelas Pancasila yang bisa diperas jadi Trisila dan Ekasila, yang secara pelan-pelan hilangkan sebutan sila pertama Ketuhanan Yang Maha Esa menjadi Ketuhanan yang berkebudayaan yang menggugah bangkitnya umat Islam untuk kembali memusuhi kaum Nasionalis. Nasionalis akan bangkitkan kembali komunisme dengan menggantikan Negara yang berazaskan sosialis seperti Perancis, China, Soviyet, Jerman, Kurchooy. 
Demikian teganya rezim di tengah pandemic akan mengambil kesempatan menggolkan konsepnya menggantikan sila pertama dengan ideology lain. Padahal Pancasila sudah ditetapkan sebagai Grand Norm, sumber Norma Moral yang mampu menciptakan masyarakat yang stabil terintegrasi yang penuh kedamaian yang konstan cukup lama, bahkan terbukti bisa menolak paham yang berusaha mencabik-cabik kerukunan bangsa mampu disngkirkan dengan tragedy gerapak 30 September 1965. Kini secara pelan-pelan akan Rezim ulangi dengan bangkitkan ide mengganti Pancasila jadi Trisila dan Ekasila dengan hapuskan Tuhan Yang Maha Esa menjadi Ketuhanan yang berkebudayaan dengan cara licik melalui jalan tipu muslihat.

\section{KESIMPULAN}

Berdasarkan uraian di atas, maka dapat penulis ringkas dari pembahasan mengenai wajar kita saatnya kembali memperhatikan pada Norma Moral sebagai sumber sumber hukum, sebagaimana pada pendiri Negara bangsa ini menetapkan Pancasila sebagai sumber dari segala sumber hukum (Grand Norm). Karena Pancasila sebagai segala sumber Norma Moral bangsa yang luhur, maka dengan ini penulis kembali ajak pada para penyelenggara ini untuk kembali buka Deklarasi dan Aklamasi yang sudah ditetapkan kala Negara bangsa ini di Proklamirkan.

1. Pernyataan Pertama Pancasila sebagai Harga Mati yang tidak bias diubah-ubah lagi.

2. Mengajak pada kita semua untuk bangun kesatuan dan persatuan yang sudah tercipta yang teori Durkheim sebut kita telah tercipta suatu roh yang mengikat orang-orang pada kerangka keyakinan: bahwa kebersamaan dalam membangun hidup yang terintegrasi yang smua itu merupakan unsur ensensial dari munculnya dimensi moral dari hukum yang bersumber pada Pancasila bukan Trisila dan Ekasila.

3. Renungi pendapat bagus HLA Hart menyatakan bahwa : Perintah (command) adalah "Toexcrcise authority over mon, non power to intrict harm, and though it may be cambined with threats of harm the command is primarity an appeal not fear but respect for authority artinya : perintah adalah tindakan melaksanakan kekuasaan terhadap seseorang, bukan berarti kekuasaan untuk menyakiti atau menimbulkan kerugian, meskipun perintah yang bersangkutan, mungkin saja terjadi bersama-sama dengan ancaman untuk terjadinya bahaya. Mohon ini sebagai kata mutiara, maka jangan sampai RUU HIP terwujud dengan gunakan Pancasila yang merupakan sumber moral, sumber nilai berubah menjadi sesuai yang menjadi suatu ancaman kehidupan berbangsa dan bernegara, yang kini sudah tercipta, hanya gara-gara satu orang tokoh yang merasa konsidi dahulu (Trisila - Ekasila) pernah gagal karena terjadi sesuatu tragedy yang menyakiti bangsa khususnya umat Islam dan TNI korban Gerakan 30 September 1965. Puncaknya pelanggaran moral ketika Peraturan KPU yang menetapkan Presiden dan Wakil Presiden pemenang Pemuli kini dibatalkan MA. Namun temingnya tidak tepat. 


\section{Makhfudz}

\section{Renungi dalam-dalam:}

Sebagai tokoh bangsa tak boleh lagi sampai dendam terhadap kelompok yang dulu dianggap menyebabkan gagalnya terwujudnya Trisila dan Ekasila yaitu kelompok Islam.

\section{Saran}

Seyogyanya dalam kehidupan berbangsa ini jangan ada merasa dirinya kelompok yang memiliki konsep yang paling benar dalam menciptakan kehidupan yang terintegrasi, nyaman, penuh kedamaian yang sudah tercipta dengan menempatkan Pancasila dengan sila-silanya yang bagus, sudah taka da yang merasa paling diperhatikan dari Pancasila ini. Anda semua pasti mendalami sejarah betapa toleransinya umat Islam kala itu dengan telah memiliki "Piagam Jakarta yang secara jelas-jelas perkuat pengakuan syariat Islam tetapi Umat Islam kala itu yang dipelopori para kyai masuk dalam panitia kecil Perumus Dasar Negara Pancasila, rela melepaskan isi dari Pancasila yang ada di Piagam Jakarta itu menjadi Ketuhanan Yang Maha Esa sebagai dasar yang mampu menaungi seluruh agama atau keyakinan lain menjadi satu di bawah Dasar Negara Pancasila.

\section{REFERENSI}

Aji, A.M; Yunus, NR, Basic Theory of Law and Justrice, Jakarta: Jurisprudence Iinstiture.

Restorasi Pancasila, Mendamaikan Politik Identitas dan Modrnitas, Proseding Simposium Peringatan Hari Lahirnya Pancasila, Kampus FISIP UI Depok 31 Mei 2006.

Jurnal Konstitusi Vol. 7 Nomor 5 Jakarta Oktober 2010 ISSN 18297706.

Sutrisno Djoko, Metodologi Penelitian Manajemen, Penerbit Puslitbang BKN 2006.

Sutrisno, Hadi, Metodologi Research, Penerbit Andi Yogya, 2004.

Yunus N R, Restorasi Budaya Hukum Masyarakat Indonesia, Jakarta Yudisprudence, Press 2012.

Willim M. Evan, Social Structurs and Law Dalam Buku Teori Hukum, Strategi Tertib Manusia Lintas Ruang dan Generasi, Penerbit Genta Yogya, 2010.

Bernard L. Tanya, Simanjuntak Yoan N., Hage Markus, Teori Hukum - Strategi Tertib Manusia Lintas Ruang dan Generasi, Penerbit Genta Yogya, April 2010.

Fuady, Munir, Teori-teori Besar (Grand Theory) Dalam Hukum, Penerbit Kencana Jakarta, 2013.

Yudi Latif, Wawasan Pancasila, Bintang Penuntun Untuk Pembudayaan, Penerbit Mizan Jakarta, 2018.

Yudi Latif, Kratos Minus Demos, Demokrasi Indonesia Catatan dari Bawah, Penerbit Pustaka Obor Indonesia Jakarta, 2012. 